\title{
Philosophiques
}

\section{Ouvrages reçus}

Volume 42, numéro 2, automne 2015

URI : https://id.erudit.org/iderudit/1034756ar

DOI : https://doi.org/10.7202/1034756ar

Aller au sommaire du numéro

Éditeur(s)

Société de philosophie du Québec

ISSN

0316-2923 (imprimé)

1492-1391 (numérique)

Découvrir la revue

Citer ce document

(2015). Ouvrages reçus. Philosophiques, 42(2), 451-451.

https://doi.org/10.7202/1034756ar

Ce document est protégé par la loi sur le droit d'auteur. L'utilisation des services d'Érudit (y compris la reproduction) est assujettie à sa politique d'utilisation que vous pouvez consulter en ligne.

https://apropos.erudit.org/fr/usagers/politique-dutilisation/
Cet article est diffusé et préservé par Érudit.

Érudit est un consortium interuniversitaire sans but lucratif composé de l’Université de Montréal, l'Université Laval et l'Université du Québec à Montréal. Il a pour mission la promotion et la valorisation de la recherche. https://www.erudit.org/fr/ 


\section{Ouvrages reçus}

Josiane Boulad-Ayoub (dir.). L’homme est né libre. Raison, politique, droit. Québec, PUL, coll. Mercure du Nord, 2014

Anastasios Brenner. Les textes fondateurs de l'épistémologie française: Duhem, Poincaré, Brunschvicg et autres philosophes. Paris, Éditions Hermann, 20I 5

Stéphane Chauvier. Éthique sans visage: Le problème des effets externes. Paris, Vrin, coll. Moments philosophiques, 2013

Marc Chevrier, Yves Couture et Stéphane Vibert (dir.). Démocratie et modernité: La pensée politique française contemporaine. Rennes, PUR, coll. Res Publica, 2015

Hélène Desbrousses. Politique, Etat, souveraineté: faire: Tome 1, Le lieu politique: Constitution et déconstitution. Éditions Inclinaison, $20 \mathrm{I} 5$

Thomas De Koninck. À quoi sert la philosophie? Québec, PUL, coll. Kairos, 2015

Sophie Guérard de Latour, Gabrielle Radica et Céline Spector. Le sens de la justice, une "utopie réaliste»? Rawls et ses critiques. Paris, Editions Classiques Garnier, coll. PolitiqueS, 20I 5

Jean-François Kervégan. La raison des normes: Essai sur Kant. Paris, Vrin, coll. Moments philosophiques, 20I 5

Quentin Landenne. Karl-Otto Apel, du point de vue moral. Paris, Michalon, coll. Le bien commun, 2015

Jerrold Levinson. Essais de philosophie de la musique. Définition, ontologie, interprétation. Paris, Vrin, coll. MusicologieS, 2015

Gabriel Mahéo et Emmanuel Housset (dir.). Max Scheler: Éthique et phénoménologie. Rennes, PUR, coll. Philosophica, 2015

Paolo Mancosu. Infini, logique, géometrie. Paris, Vrin, coll. Mathesis, 20 5

Louis Marion. Comment exister encore? Capital, techno-science et domination. Montréal, Ecosociété, coll. Théorie, 2015

Laurent Perreau (dir.). Le phénomène. Paris, Vrin, coll. Thema, 20I 4

Dominique Pradelle. Généalogie de la raison. Paris, PUF, coll. Épiméthée, 2013

Louis-André Richard (dir.). La cité et ses ombres, Construire une société juste. Un débat entre Mathieu Bock-Côté et Roch Bolduc. Québec, PUL, 2015

Pierre Rosanvallon. Le bon gouvernement. Paris, Seuil, coll. Les livres du nouveau monde, 2015

Alain Séguy-Duclot. Éthique. Georg Olms Verlag, coll. Europaea Memoria, 20I4

Alexandra Torero-Ibad, Delphine Kolesnik-Antoine, Josiane Boulad-Ayoub (dir.). Les arts de lire des philosophes modernes. Québec, PUL, coll. Mercure du Nord, 2015

Luc Vigneault, Navarro Pardinas Blanca, Sophie Cloutier, Dominic Desroches (dir.). Le temps de l'hospitalité. Réception de l'oeuvre de Daniel Innerarity. Québec, PUL, 2015 